\title{
Ground beetle fauna (Coleoptera, Carabidae) of Mordovia State Nature Reserve (Russia)
}

\author{
Alexander Ruchin ${ }^{\ddagger}$, Sergey Alekseev§, Leonid Egorovl, Oleg Artaev ${ }^{\Uparrow}$, Gennadiy Semishin ${ }^{\ddagger}$, \\ Mikhail Esin ${ }^{\ddagger}$ \\ $\ddagger$ Joint Directorate of the Mordovia State Nature Reserve and National Park "Smolny", Saransk, Russia \\ $\S$ Ecological club "Stenus", Kaluga, Russia \\ | Prisursky State Nature Reserve, Cheboksary, Russia \\ If Papanin Institute for Biology of Inland Waters Russian Academy of Sciences, Borok, Russia
}

Corresponding author: Oleg Artaev (artaev@gmail.com)

Academic editor: Pedro Cardoso

Received: 07 Jun 2021 | Accepted: 19 Oct 2021 | Published: 25 Oct 2021

Citation: Ruchin A, Alekseev S, Egorov L, Artaev O, Semishin G, Esin M (2021) Ground beetle fauna

(Coleoptera, Carabidae) of Mordovia State Nature Reserve (Russia). Biodiversity Data Journal 9: e69807. https://doi.org/10.3897/BDJ.9.e69807

\begin{abstract}
\section{Background}

Protected areas are organised in different climatic zones, which usually include typical ecosystems characteristic of certain climatic zones. In most cases, protected areas are biodiversity hotspots. These areas are benchmarks in terms of nature conservation and to determine their biological diversity is becoming an important task. It is important to investigate the carabid family of protected areas within the framework of understanding the overall biological diversity of these systems. In addition, ground beetles, as one of the largest groups of ground-based inhabitants, are indicators of the state of ecosystems and serve as markers of their well-being.
\end{abstract}

\section{New information}

We present 2,969 new occurrence records comprising 226 species of Carabidae, belonging to eight subfamilies, from the Mordovia State Nature Reserve (central Russia). 
Ten species are listed for the first time for the Mordovia State Nature Reserve fauna after previous research: Cicindela maritima, Bembidion striatum, Dyschirius angustatus, Dyschirius arenosus, Notiophilus aestuans, Bembidion argenteolum, Bembidion velox, Bradycellus caucasicus, Cymindis angularis and Syntomus truncatellus, five of which were first recorded for the Republic of Mordovia (Egorov et al. 2020). Previously, this information was not published anywhere and we wanted to make it available to everyone by embedding it in the global database on biodiversity (GBIF).

\section{Keywords}

biodiversity, Coleoptera, Carabidae, pitfall traps, Republic of Mordovia

\section{Introduction}

Anthropogenic disturbances, such as urbanisation, toxic chemical pollution, more frequent and intense fires, deforestation and climate change have recently had a significant impact on biodiversity in many ecosystems. Insects play an important role in the functioning of ecosystems and a decrease in their biodiversity can cause serious disruptions of natural processes. However, there is a lack of data on the diversity, abundance, phenology and other biological traits of many insect groups that play a crucial role in ecosystems (Butchart et al. 2010, Bondarenko et al. 2020). Ground beetles (Coleoptera, Carabidae) are important predators of other insects and are considered economically useful in agricultural systems (Sklodowski and Garbalinska 2011, Ruchin et al. 2019, Rozhnov et al. 2019). As ground beetles are diverse and abundant in the ground layer of landscapes with varying degrees of disturbance, they have been used as bioindicators to assess ecosystem health (Rainio and Niemelä 2003, Noordijk et al. 2008, Venn et al. 2013, Zamotajlov et al. 2019). Thus, documenting ground beetle diversity and distribution in natural ecosystems, such as the Mordovia State Nature Reserve, provides critical baseline data that can be used for future comparisons with more disturbed sites. Additionally, these data can be used in bioindication, for a general understanding of ecosystem biodiversity and for the protection of individual species and ecosystems.

From the published dataset, five taxa are recommended for inclusion in the Red Data Book of the region (Carabus nitens, Calosoma inquisitor, Carabus aurolimbatus, Carabus schoenherri and Lebia marginata). These are rare and protected species. At the same time, Lebia marginata was found within the region only within the territory of the Mordovian Reserve.

\section{Sampling methods}

Study extent: The Mordovia State Nature Reserve is located in the Republic of Mordovia (Central Russia). Its area is $321.62 \mathrm{~km}^{2}$. Forests cover $89.3 \%$ of the Mordovia State Nature Reserve. The main type of forest is pine (Pinus sylvestris) forests. Pure and mixed stands 
of pine dominate the southern, central and western parts. Birch (Betula pendula) forests grow in burned areas and are the second most common forest type. Deciduous forests with Quercus robur and Tilia cordata are located in small areas in the northern, western and south-western parts. Small patches of forest, dominated by Picea abies and Alnus glutinosa, are located mainly in the floodplains of small rivers and streams (Khapugin et al. 2016, Ruchin and Makarkin 2017).

Quality control: Each observation includes fundamental information, such as location (latitude/longitude), date, name of observer and name of the identifier. Coordinates were determined on site with a GPS device (various models of smartphones) or after the fact using Google Maps. We used conventional methods for collecting ground beetles, including hand-collecting, pitfall traps, light trapping and partial beer traps (Golub et al. 2012, Ruchin et al. 2020). Pitfall traps (the primary method) were deployed during AprilAugust (sometimes September) 2008-2020. The traps were 0.5-litre cups containing 200 $\mathrm{ml}$ of $4 \%$ formalin solution. In each habitat, we installed 10 traps along a transect with 2-3 $\mathrm{m}$ between consecutive traps. The collected material was determined by $\mathrm{S}$. Alekseev and L. Egorov. Determination was carried out according to Isaev (2002), MÜLLER-MOTZFELD (2004). We followed the nomenclature proposed in Kryzhanovskij et al. (1995),Lobl and Lobl (2017).

\section{Geographic coverage}

Description: The dataset provides new records of Carabidae (Coleoptera) from the territory of the Mordovia State Nature Reserve (Russian Federation).

Coordinates: $54^{\circ} 42^{\prime} 24^{\prime \prime} \mathrm{N}$ and $54^{\circ} 56^{\prime} 08^{\prime \prime N}$ Latitude; $43^{\circ} 04^{\prime 2} 28^{\prime \prime E}$ and $43^{\circ} 37^{\prime} 49^{\prime \prime E}$ Longitude.

\section{Taxonomic coverage}

Description: All individuals of Carabidae were identified to the species level. The taxonomic diversity of the study area is represented by 226 species belonging to eight subfamilies. Ten species are listed for the first time for the Mordovia State Nature Reserve fauna in this study. According to the literature (Ruchin et al. 2019, Egorov et al. 2020), another 15 species are known in the research area and not captured during our studies. Given the long-term nature of our focused research, this is an almost exhaustive list of species that have breeding populations in Mordovia State Nature Reserve (241 species) (Alekseev et al. 2021).

Taxa included:

\begin{tabular}{|l|l|}
\hline Rank & Scientific Name \\
\hline phylum & Arthropoda \\
\hline class & Insecta \\
\hline
\end{tabular}




\begin{tabular}{|c|c|}
\hline order & Coleoptera \\
\hline family & Carabidae \\
\hline subfamily & Carabinae \\
\hline subfamily & Elaphrinae \\
\hline subfamily & Harpalinae \\
\hline subfamily & Loricerinae \\
\hline subfamily & Nebriinae \\
\hline subfamily & Patrobinae \\
\hline subfamily & Scaritinae \\
\hline subfamily & Trechinae \\
\hline
\end{tabular}

\section{Temporal coverage}

Data range: 2008-4-01 - 2020-6-07.

\section{Usage licence}

Usage licence: Other

IP rights notes: Creative Commons Attribution (CC-BY) 4.0 License

\section{Data resources}

Data package title: Carabidae of Mordovia State Nature Reserve

Resource link: https://www.gbif.org/dataset/4b901e9a-18c4-473c-a56d-b7689b55ecbc

Alternative identifiers: https://doi.org/10.15468/9s9z7s

\section{Number of data sets: 1}

Data set name: Carabidae of Mordovia State Nature Reserve

\begin{tabular}{|l|l|}
\hline Column label & Column description \\
\hline occurrencelD & The globally unique identifier number for the record \\
\hline basisOfRecord & The specific nature of the data record: HumanObservation \\
\hline eventDate & date format as YYYY-MM-DD \\
\hline scientificName & $\begin{array}{l}\text { The full scientific name including the genus name and the lowest level of } \\
\text { taxonomic rank with the authority }\end{array}$ \\
\hline
\end{tabular}




\begin{tabular}{|c|c|}
\hline kingdom & The full scientific name of the kingdom in which the taxon is classified \\
\hline phylum & The full scientific name of the phylum or division in which the taxon is classified \\
\hline class & The full scientific name of the class in which the taxon is classified \\
\hline order & The full scientific name of the order in which the taxon is classified \\
\hline family & The full scientific name of the family in which the taxon is classified \\
\hline decimalLatitude & The geographic latitude of location in decimal degrees \\
\hline decimalLongitude & The geographic longitude of location in decimal degrees \\
\hline coordinateUncertaintyInMetres & $\begin{array}{l}\text { The horizontal distance (in metres) from the given decimalLatitude and } \\
\text { decimalLongitude describing the smallest circle containing the whole of the } \\
\text { Location }\end{array}$ \\
\hline geodeticDatum & $\begin{array}{l}\text { The ellipsoid, geodetic datum or spatial reference system (SRS) upon which the } \\
\text { geographic coordinates given in decimalLatitude and decimalLongitude are based }\end{array}$ \\
\hline Country & The name of the country or major administrative unit in which the Location occurs \\
\hline countryCode & The standard code for the country in which the Location occurs \\
\hline individualCount & The number of individuals present at the time of the Occurrence \\
\hline year & Year the event was recorded \\
\hline month & The month the event was recorded \\
\hline day & The integer day of the month on which the Event occurred \\
\hline recordedBy & A person or group responsible for recording the original Occurrence \\
\hline identifiedBy & A list of names of people, who assigned the Taxon to the subject \\
\hline
\end{tabular}

\section{Author contributions}

Alexander Ruchin - conceptualisation, methodology, investigation, validation, original draft preparation; Sergey Alekseev - identification of the material, analysis; Leonid Egorov methodology, identification of the material, analysis; Oleg Artaev - investigation, software, validation, editing; Gennadiy Semishin - investigation; Mikhail Esin - investigation.

\section{References}

- $\quad$ Alekseev S, Ruchin A, Egorov L, Artaev O, Semishin G, Esin M (2021) Carabidae of Mordovia State Nature Reserve. 1.7. Joint Directorate of the Mordovia State Nature Reserve and National Park "Smolny". Release date: 2021-5-14. URL: https://doi.org/ $10.15468 / 9 \mathrm{~s} 9 \mathrm{z} 7 \mathrm{~s}$

- Bondarenko A, Zamotajlov A, Belyi A, Khomitskiy E (2020) Fauna and ecological characteristics of ground beetles (Coleoptera, Carabidae) of the Nature Sanctuaries 
"Prichernomorskiy" and "Tuapsinskiy" (Russia). Nature Conservation Research 5 (3). https://doi.org/10.24189/ncr.2020.032

- Butchart SHM, Walpole M, Collen B, van Strien A, Scharlemann JPW, Almond REA, Baillie JEM, Bomhard B, Brown C, Bruno J, Carpenter KE, Carr GM, Chanson J, Chenery AM, Csirke J, Davidson NC, Dentener F, Foster M, Galli A, Galloway JN, Genovesi P, Gregory RD, Hockings M, Kapos V, Lamarque J-, Leverington F, Loh J, McGeoch MA, McRae L, Minasyan A, Morcillo MH, Oldfield TEE, Pauly D, Quader S, Revenga C, Sauer JR, Skolnik B, Spear D, Stanwell-Smith D, Stuart SN, Symes A, Tierney M, Tyrrell TD, Vie JC, Watson R (2010) Global biodiversity: Indicators of recent declines. Science 328 (5982): 1164-1168. https://doi.org/10.1126/science.1187512

- Egorov L, Ruchin A, Semenov V, Semionenkov O, Semishin G (2020) Checklist of the Coleoptera of Mordovia State Nature Reserve, Russia. ZooKeys 962: 13-122. https://doi.org/10.3897/zookeys.962.54477

- $\quad$ Golub VB, Tsurikov MN, Prokin AA (2012) Insect collections: collection, processing and storage of material. KMK Scientific Press Ltd, Moscow, 339 pp. [In Russian].

- Isaev AY (2002) Определитель жесткокрылых Среднего Поволжья. Часть 1. Adephaga и Myxophaga. [Keys to Coleoptera of the Middle Volga Region. Part 1. Adephaga and Myxophaga]. Series Nature of the Ulyanovsk region, Ulyanovsk. [In Russian].

- Khapugin A, Vargot E, Chugunov G (2016) Vegetation recovery in fire-damaged forests: a case study at the southern boundary of the taiga zone. Forestry Studies 64 (1): 39-50. https://doi.org/10.1515/fsmu-2016-0003

- $\quad$ Kryzhanovskij OL, Belousov IA, Kabak II, Kataev BM, Makarov KV, Shilenkov VG (1995) A Checklist of the Ground-Beetles of Russia and Adjacent Lands (Insecta, Coleop-tera, Carabidae). PENSOFT Publishers, Sofia - Moscow, 271 pp.

- Lobl I, Lobl D (2017) Catalogue of Palaearctic Coleoptera - Volume 1, Revised and Updated Edition, 2017. Brill Online https://doi.org/10.6084/m9.figshare.5240644.v1

- $\quad$ MÜLLER-MOTZFELD G (2004) Bd. 2, Adephaga 1: Carabidae (Laufkäfer). In: FREUDE H, HARDE KW, LOHSE GA, KLAUSNITZER B (Eds) Die Käfer Mitteleuropas. Spektrum-Verlag, Heidelberg/Berlin.

- $\quad$ Noordijk J, Schaffers A, Sykora K (2008) Diversity of ground beetles (Coleoptera: Carabidae) and spiders (Araneae) in roadside verges with grey hair-grass vegetation. European Journal of Entomology 105 (2): 257-265. https://doi.org/10.14411/eje. 2008.036

- $\quad$ Rainio J, Niemelä J (2003) Ground beetles (Coleoptera: Carabidae) as bioindicators. Biodiversity and Conservation 12 (3): 487-506. https://doi.org/10.1023/a: 1022412617568

- $\quad$ Rozhnov V, Lavrinenko I, Razzhivin V, Makarova O, Lavrinenko O, Anufriev V, Babenko A, Bizin M, Glazov P, Goryachkin S, Kolesnikova A, Matveyeva N, Pestov S, Petrovskii V, Pokrovskaya O, Tanasevich A, Tatarinov A (2019) Biodiversity revision of a large arctic region as a basis for its monitoring and protection under conditions of active economic development (Nenetsky Autonomous Okrug, Russia). Nature Conservation Research 4 (2). https://doi.org/10.24189/ncr.2019.015

- $\quad$ Ruchin A, Makarkin V (2017) Neuroptera and Raphidioptera in the Mordovia State Nature Reserve. Nature Conservation Research 2 (2). [In Russian]. https://doi.org/ 10.24189/ncr.2017.001 
- Ruchin A, Alekseev S, Khapugin A (2019) Post-fire fauna of carabid beetles (Coleoptera, Carabidae) in forests of the Mordovia State Nature Reserve (Russia). Nature Conservation Research 4 https://doi.org/10.24189/ncr.2019.009

- Ruchin A, Egorov L, Khapugin A, Vikhrev N, Esin M (2020) The use of simple crown traps for the insects collection. Nature Conservation Research 5 (1). https://doi.org/ 10.24189/ncr.2020.008

- $\quad$ Sklodowski J, Garbalinska P (2011) Ground beetle (Coleoptera, Carabidae) assemblages inhabiting Scots pine stands of Puszcza Piska Forest: six-year responses to a tornado impact. ZooKeys 100: 371-392. https://doi.org/10.3897/zookeys.100.1360

- Venn S, Kotze DJ, Lassila T, Niemelä J (2013) Urban dry meadows provide valuable habitat for granivorous and xerophylic carabid beetles. Journal of Insect Conservation 17 (4): 747-764. https://doi.org/10.1007/s10841-013-9558-8

- Zamotajlov A, Serdyuk V, Khomitskiy E, Belyi A (2019) New data on distribution and biology of some rare ground beetles (Coleoptera, Carabidae) in South Russia. Nature Conservation Research 4 (4). [In Russian]. https://doi.org/10.24189/ncr.2019.066 